\title{
Simultaneous generation of Bioelectricity and Treatment of Swine wastewater in a Microbial Fuel Cell
}

\author{
Egbadon, Emmanuel. $\mathrm{O}^{1, a *}$, Akujobi, Campbell. $\mathrm{O}^{1, \mathrm{~b}}$, \\ Nweke, Chris. ${ }^{1, \mathrm{c}}$, Braide, Wesley ${ }^{1, \mathrm{~d}}$, \\ Akaluka, Cynthia. $\mathrm{K}^{1, \mathrm{e}}$ and Adeleye, Samuel. $\mathrm{A}^{1, \mathrm{f}}$ \\ ${ }^{1}$ Department of Microbiology, Federal University of Technology Owerri, Imo state, Nigeria. \\ aemmanuelegbadon@gmail.com*, bcampbell205@yahoo.com, xrisokey@yahoo.com, \\ dwesleybraide@yahoo.com, ${ }^{\mathrm{d}}$ reachkaysea@yahoo.com, ${ }^{\mathrm{f}}$ adeleyesamuela@gmail.com \\ ${ }^{*}$ Corresponding author
}

Keywords: Bioelectricity, Swine wastewater treatment, Microbial Fuel Cell (MFC).

\begin{abstract}
This study aimed at the simultaneous treatment of wastewater obtained from swine and generation of bioenergy in form of electricity from the energy stored in the organic component of the wastewater. The Open circuit voltage, current, power density and microbiological and physicochemical parameters were monitored. An initial Open circuit voltage of $516 \mathrm{mV}$, Current of $0.29 \mathrm{~mA}$, and Power density of $32.74 \mathrm{~mW} / \mathrm{m}^{2}$ were recorded, which increased to give maximum Open Circuit Voltages of $836 \mathrm{mV}$, Current of $0.49 \mathrm{~mA}$, and Power density of $88.45 \mathrm{~mW} / \mathrm{m}^{2}$. The results revealed that The Chemical Oxygen Demand (COD), Biochemical Oxygen Demand (BOD), Organic carbon, Total Soluble solids (TSS), Ammonia, Ammonium and Ammonium-Nitrogen all showed percentage decrease of $85.92 \%, 51.74 \%, 78.16 \%, 98.87 \%, 55.87 \%, 55.79 \%$ and $55.90 \%$ respectively while parameters such as Total Dissolved Solids (TDS), Nitrate, Nitrate-Nitrogen, Phosphates, Phosphorus and Orthophosphates however increased after treatment to give a percentage increase of $-273.60 \%,-131.65 \%,-134.85 \%,-168.77 \%,-159.26 \%$, and $-157.03 \%$ respectively. Bacteria isolates identified at the biofilms on the anode were Corynebacterium specie, Bacillus specie, Staphylococcus aureus, Escherichia coli, Pseudomonas aeruginosa and Streptococcus faecalis. The results from this study further exacerbate the Bioelectricity production as well as wastewater treatment potentials of the Microbial Fuel Cell technology.
\end{abstract}

\section{INTRODUCTION}

Energy demand in the agricultural sector is on the increase as the economy of most countries are currently partly dependent on its output. The available sources of energy are not able to satisfy this demand due to their cost, inaccessibility as well as non-ecofriendly [1]. Sustainable treatment and utilization of wastewater are receiving intensive attention due to the growing shortage of freshwater resources, depletion of fossil fuel, and environmental pollution. At present, most traditional wastewater treatment processes consume energy and cause environmental problems [2]. The agricultural sector is a major waste stream and its waste could be converted to wealth using several green technologies ranging from the use of anaerobic digestion to the current trends of biological electrochemical systems. Microbial fuel cell is one of the biological electrochemical systems with promising capability to treat waste generated from agro farms and in return produce electricity. The microbial fuel cell (MFC) technology has been intensively researched in the recent decade, because it offers a solution for environmental sustainability by simultaneously performing pollutant removal and energy production. MFCs use exoelectrogenic microorganisms to convert the chemical energy stored in biodegradable substances to direct electricity [3]. A simple microbial fuel cell consists of an anode (substrate tank), a proton exchange membrane and a Cathode (electron acceptor) as seen in different research works [1]. The H-Type microbial fuel cell is used commonly for research purposes but is limites by high internal resistance [4]. Swine waste water, as one of the agrosourced waste, is energy rich and can constitute a nuisance to the environment if discharged untreated. Swine wastewater treatment and odor control are important components for sustainable 
animal production [5]. This research examines the potential of the H-type microbial fuel cell to treat swine wastewater and simultaneously produce electricity using ferricyanide as catholyte.

\section{MATERIALS AND METHODS}

\section{Collection of Swine Wastewater Sample}

The swine wastewater samples were collected from a Pig farm at Old Nekede road, Owerri, Imo state. The samples were collected according to the methods described by [6]. Swine wastewater samples were collected in a four (4) litre container that was treated with alcohol, washed properly with tap water, rinsed with the swine wastewater sample to be collected and then filled up with the wastewater samples.

\section{Physicochemical analysis}

Some physicochemical parameters were analysed. They include; $\mathrm{pH}$, Temperature, Conductivity $(\mu \mathrm{S} / \mathrm{cm})$, Chemical Oxygen Demand (COD) (mg/l), Biochemical Oxygen Demand (BOD) (mg/l), Organic Carbon (\%), Total Soluble Solids (mg/l), Total Dissolved Solids (mg/l), Nitrate (mg/l), Nitrate-Nitrogen $(\mathrm{mg} / \mathrm{l})$, Phosphate $\left(\mathrm{PO}_{4}{ }^{3-}\right)(\mathrm{mg} / \mathrm{l})$, Phosphorus $(\mathrm{P})(\mathrm{mg} / \mathrm{l})$, Phosphate $\left(\mathrm{P}_{2} \mathrm{O}_{5}\right)(\mathrm{mg} / \mathrm{l})$, Ammonia (mg/l), Ammonia-Nitrogen (mg/l) and Ammonium (mg/l). Chemical Oxygen Demand (COD), Nitrate, Nitrate-Nitrogen, Phosphate $\left(\mathrm{PO}_{4}{ }^{3-}\right)$, Phosphorus (P), Phosphate $\left(\mathrm{P}_{2} \mathrm{O}_{5}\right)$, Ammonia, Ammonia-Nitrogen and Ammonium (mg/l) analysis was carried out using HANNA instrument Multiparameter Photometer Model No. HI: 80399. USA. BOD was analysed using the dilution method. Conductivity and TDS were analysed using the using HANNA instrument Portable pH/EC/TDS/Temperature meter Model No.: HI 991301.

\section{Bacteria isolates identification}

Bacteria isolates present in the swine wastewater were identified on the basis of staining procedures and biochemical tests as described [7] before and after operation of the MFC.

\section{Construction and Operation of Microbial Fuel Cell}

The traditional H-Type Dual-chamber MFC was constructed using non-reactive polyacrylic containers. It was constructed using non-reactive polyacrylic containers of $1100 \mathrm{ml}$ with a working volume of $1000 \mathrm{ml}$. One polyacrylic container was used as the anode chamber and the other polyacrylic plastic container used as the cathode chamber. $1000 \mathrm{ml}$ of the substrate (wastewater) was fed into the anode chamber while the catholyte (100mM Potassium Ferricyanide solution) was fed into the cathode chamber. Agar-salt Bridge (Proton exchange membrane) was prepared using $2 \%$ Agar and $1 \% \mathrm{NaCl}$. The length and diameter of the agar-salt bridge $10 \mathrm{~cm} \times 3 \mathrm{~cm}$ respectively. This Agar-salt Bridge (Proton exchange membrane) was used as the connector between the anode and cathode chamber and was prepared according to methods described in [8]. The electrodes used were rod-shaped carbon electrodes of length and diameter $12 \mathrm{~cm} \times 1.2 \mathrm{~cm}$ respectively. The electrodes were placed in the anode and cathode chamber and connected to a copper wire [9], sealed and made air-tight.

The Swine wastewater was used as the substrate as well as the source of the inoculum such that the bacteria present will utilize the nutrient present in the wastewater. No other form of nutrients was added to the wastewater. The $\mathrm{pH}$ of the wastewater was not adjusted. The rod-shaped carbon electrodes were sanded lightly to facilitate bacterial attachment to the surface of the electrodes [1]. The ambient temperature varied between $27^{\circ} \mathrm{C}$ to $32^{\circ} \mathrm{C}$ throughout the period of the experiments. The setup were allowed to stand for 21 days and open circuit voltage and current measured at intervals of 3 hours each day using a digital multimeter (Model: DT830) [10].

Determination of Percentage (\%) change of Physicochemical Parameters Changes in physicochemical parameters measured in percentage $(\%)$ were determined using the formula below:

$$
\text { Percentage (\%) Change }=\frac{\text { initial }- \text { final }}{\text { initial }} \times 100 \quad \text { Equation (1) }
$$


Changes in percentage (\%) in physicochemical parameter as determined from Equation (1) gives an indication of either an increase or decrease of the physicochemical measured in percentage after 21 days (504 hours) of operation of MFC.

\section{Catholyte Preparation}

Potassium Ferricyanide at a concentration of $100 \mathrm{mM}$ [11] was used as the catholyte. It was prepared by dissolving 32.92 grams of the salt in $1000 \mathrm{ml}$ of distilled water.

\section{Determination of Power Density}

The power density $(\mathrm{P})$ obtained from this experiment normalized by the projected surface area of the graphite rod anode $\left(\mathrm{m}^{2}\right)$ was determined using the formular; [12,13].

$$
\text { Power density }(P)=\frac{\operatorname{Current}(m A) \times \operatorname{Volts}(V)}{\text { Surface area of projected anode }\left(\mathrm{m}^{2}\right)}
$$

Equation (2)

Where $\mathrm{P}$ is expressed in $\mathrm{mW} / \mathrm{m}^{2}$.

\section{RESULTS}

\section{Microbiological Analysis}

The bacterial isolates identified from the biofilm of the anode includes Corynebacterium specie, Bacillus specie, Streptococcus specie, Escherichia coli, Pseudomonas aeruginosa and Staphylococcus aureus were identified after MFC treatment of swine wastewater.

\section{Waste water treatment capacity of the Microbial fuel cell}

The waste water treatment capacity of the microbial fuel cell is shown in Table 1. The Chemical Oxygen Demand (COD), Biochemical Oxygen Demand (BOD), Organic carbon, Total Soluble solids (TSS), Ammonia, Ammonium and Ammonium-Nitrogen all showed percentage decrease of $85.92 \%, 51.74 \%, 78.16 \%, 98.87 \%, 55.87 \%, 55.79 \%$ and $55.90 \%$ respectively. Physicochemical parameters such as Total Dissolved Solids (TDS), Nitrate, Nitrate-Nitrogen, Phosphates, Phosphorus and Orthophosphates however increased after treatment to give a percentage increase of $-273.60 \%,-131.65 \%,-134.85 \%,-168.77 \%,-159.26 \%$, and $-157.03 \%$ respectively.

Table 1: Physicochemical characteristic of Swine wastewater

\begin{tabular}{|c|c|c|c|}
\hline $\begin{array}{l}\text { Physicochemical } \\
\text { Parameter }\end{array}$ & $\begin{array}{l}\text { Before } \\
\text { Treatment }\end{array}$ & $\begin{array}{l}\text { After } \\
\text { Treatment }\end{array}$ & $\begin{array}{l}\text { Percentage (\%) } \\
\text { Change }\end{array}$ \\
\hline $\mathrm{pH}$ & 9.1 & 8.3 & \\
\hline Conductivity $(\mu \mathrm{S} / \mathrm{cm})$ & 1893 & 7070 & \\
\hline $\begin{array}{l}\text { Chemical Oxygen Demand } \\
(\mathrm{COD})(\mathrm{mg} / \mathrm{l})\end{array}$ & 5400 & 760 & 85.92 \\
\hline $\begin{array}{l}\text { Biochemical Oxygen } \\
\text { Demand (BOD) (mg/l) }\end{array}$ & 1450 & 700 & 51.74 \\
\hline Organic Carbon $(\%)$ & 0.87 & 0.19 & 78.16 \\
\hline Total Soluble Solids (mg/l) & 31420 & 356 & 98.87 \\
\hline $\begin{array}{lll}\text { Total } & \text { Dissolved } & \text { Solids } \\
(\mathrm{mg} / \mathrm{l}) & \end{array}$ & 1230.05 & 4595.5 & -273.60 \\
\hline Nitrate $(\mathrm{mg} / \mathrm{l})$ & 297 & 688 & -131.65 \\
\hline Nitrate-Nitrogen (mg/l) & 66 & 155 & -134.85 \\
\hline Phosphate $\left(\mathrm{PO}_{4}{ }^{3-}\right)(\mathrm{mg} / \mathrm{l})$ & 333 & 895 & -168.77 \\
\hline Phosphorus (P) (mg/l) & 108 & 280 & -159.26 \\
\hline Phosphate $\left(\mathrm{P}_{2} \mathrm{O}_{5}\right)(\mathrm{mg} / \mathrm{l})$ & 249 & 640 & -157.03 \\
\hline Ammonia (mg/l) & 630 & 278 & 55.87 \\
\hline Ammonia-Nitrogen (mg/l) & 518 & 229 & 55.79 \\
\hline Ammonium (mg/l) & 669 & 295 & 55.90 \\
\hline
\end{tabular}


Voltage and current Generated During MFC Operation of Swine Wastewater

The results for the Open Circuit Voltage (OCV) generated during the operation of MFC for treatment of Abattoir wastewater is shown in Figure 1. The maximum Open Circuit Voltage (OCV) generated was $836 \mathrm{mV}(0.836 \mathrm{~V})$. The voltage after the first 3 hours of pitching was $516 \mathrm{mV}$, increasing to $768 \mathrm{mV}$ after 27 hours, and then peaking at $836 \mathrm{mV}$ after 186 hours. It however decreased to $541 \mathrm{mV}$ after 330 hours. The least voltage recorded after 504 hours was $351 \mathrm{mV}$. The Maximum Current in $\mathrm{mA}$ (milliAmperes) generated was $0.49 \mathrm{~mA}$. After 3 hours of pitching the current recorded was $0.29 \mathrm{~mA}$, increasing over time to peak at $0.49 \mathrm{~mA}$ after 78 hours. The current decreased to $0.40 \mathrm{~mA}$ after 204 hours then fluctuating over time. It however reduced to $0.14 \mathrm{~mA}$ after 492 hours remaining constant for the remaining 12 hours of operation.

\section{Power Density Generated During Swine Wastewater Treatment}

The results from the Fig 2 below shows that the maximum Power density generated from the 504 hour treatment of Swine wastewater using Microbial Fuel Cell was $88.45 \mathrm{~mW} / \mathrm{m}^{2}$. The initial power density generated at the beginning of the experiment for the treatment of swine wastewater using the dual-chamber microbial fuel cell was $32.74 \mathrm{~mW} / \mathrm{m}^{2}$. From Figure 2 below it can be observed that the power dropped to $3.55 \mathrm{~mW} / \mathrm{m}^{2}$ after 330 hours. It however increased within a short time to reach a value of $30.69 \mathrm{~mW} / \mathrm{m}^{2}$ after 411 hours. It remained fairly constant ranging between 20$27 \mathrm{~mW} / \mathrm{m}^{2}$ before dropping finally to $10.75 \mathrm{~mW} / \mathrm{m}^{2}$.

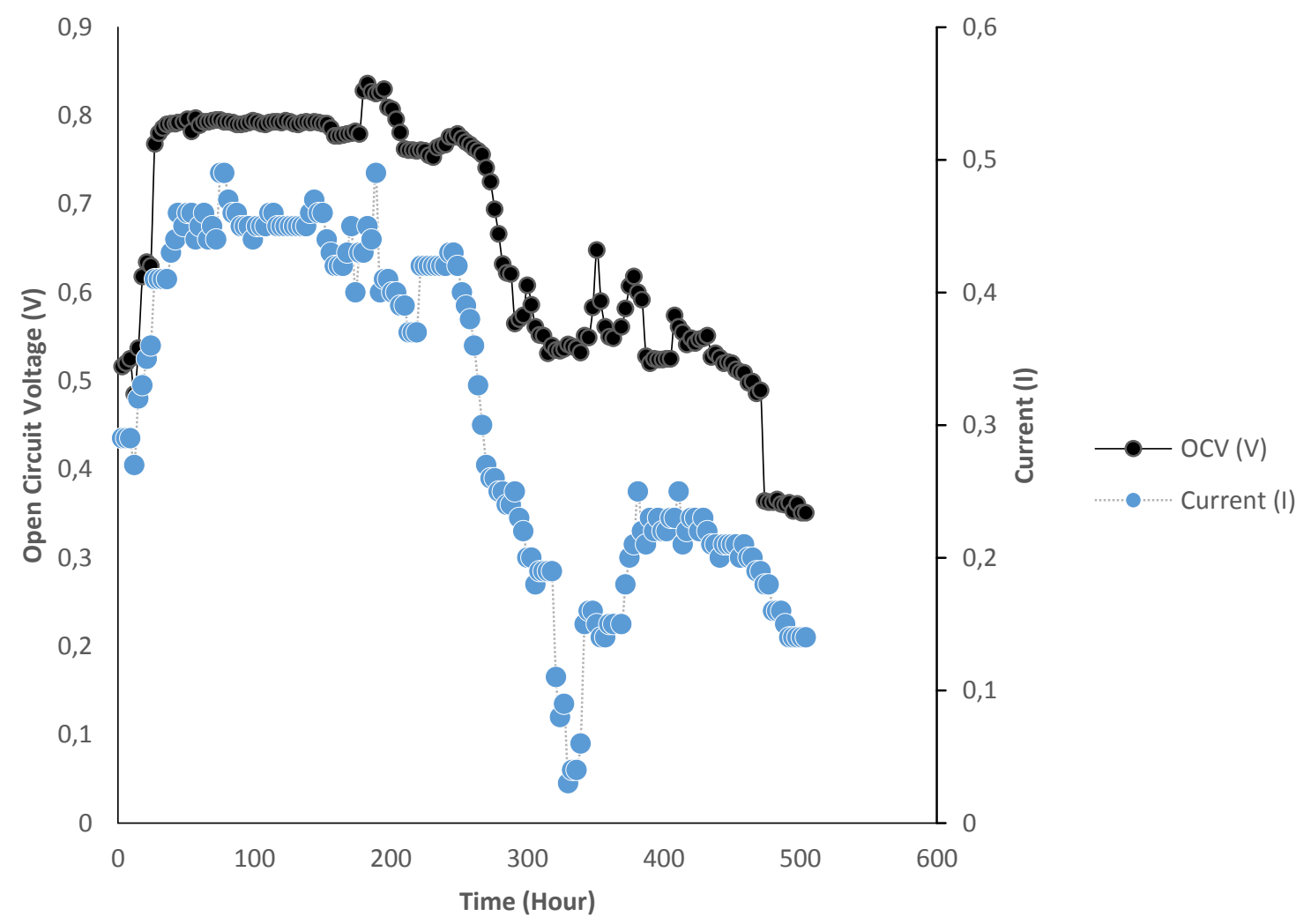

Figure 1: Open circuit voltage (OCV) generated per Time during treatment of Swine wastewater 


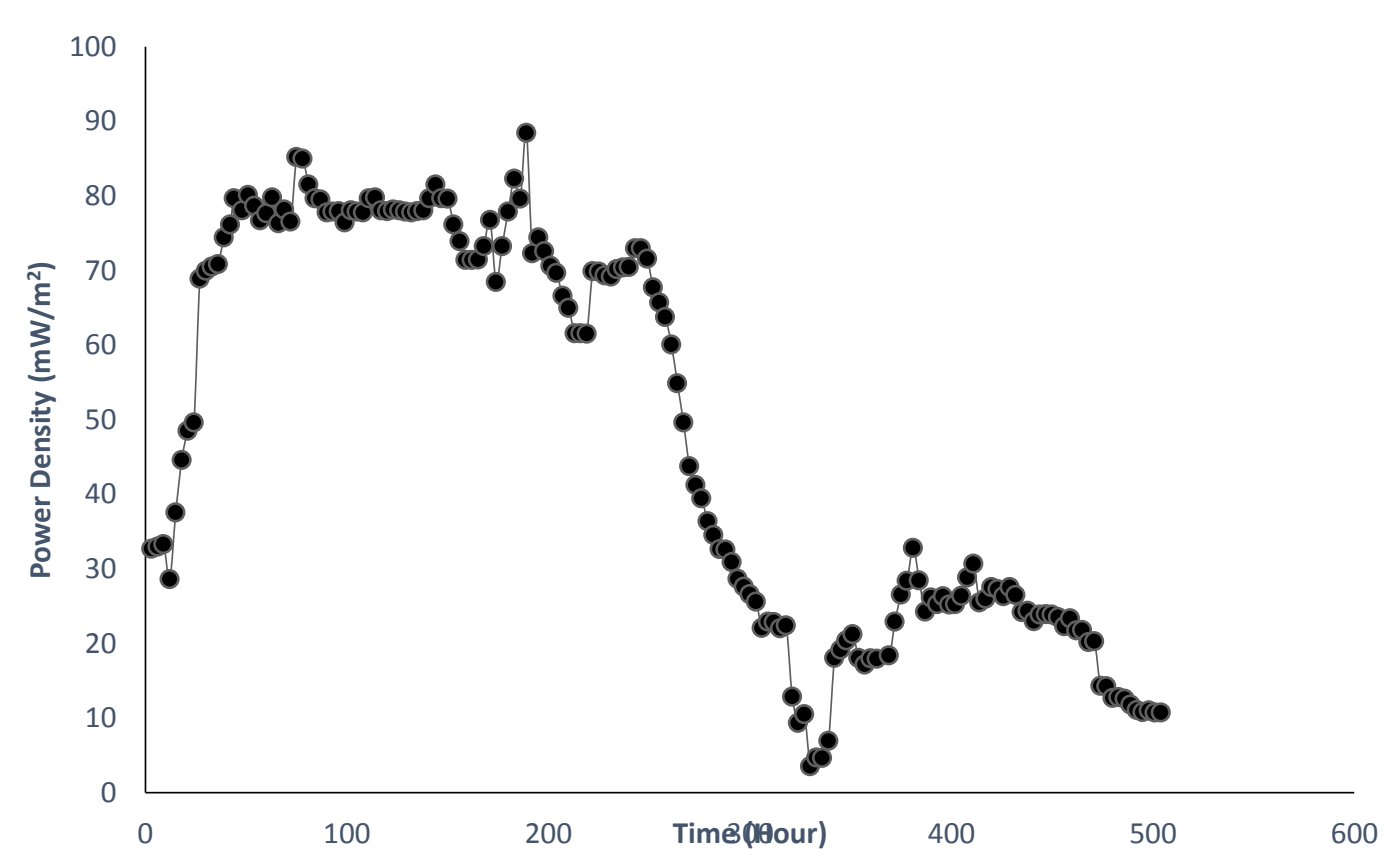

Figure 2: Power Density Generated per Time for treatment of Swine wastewater

\section{DISCUSSION}

An important aim in this study was to identify potential bioelectricity generating bacteria from swine wastewaters. Isolates obtained from Swine wastewater includes Corynebacterium specie, Bacillus specie, Staphylococcus aureus, Escherichia coli, Pseudomonas aeruginosa and Streptococcus faecalis. Potential bioelectricity generating isolates used in previous studies includes Clostridium species [14,15], Geobacter sulfureducens [16], Shewanella japonica [17], Shewanella putrefaciens [10], Klebsiella specie [18], Corynebacterium species [19], Enterobacter cloacae [20], Lactococcus lactis [21] and Bacillus megaterium [22]. The bioelectrogens isolated from this experiments have also been reported as possible electrogenic bacteria that can drive the generation of electricity using the technology of MFC as reported in studies carried out by [19].

In this study, the addition of Swine wastewater to their respective chambers gave an initial Open circuit voltage of $516 \mathrm{mV}$, Current of $0.29 \mathrm{~mA}$, and Power density of $32.74 \mathrm{~mW} / \mathrm{m}^{2}$, which increased and peaked within 5-7 days of operation to give maximum Open Circuit Voltages of $836 \mathrm{mV}$, Current of $0.49 \mathrm{~mA}$, and Power density of $88.46 \mathrm{~mW} / \mathrm{m}^{2}$ respectively as shown in Figures 1 and 2 . This initial increase in voltages, currents and power densities might have resulted from both biological and chemical factors, based on the differences of the potential between the two chambers [8]. The voltage and currents were seen to decrease with time. This decrease in OCV can be attributed to the rate of utilization of the organic substrate in the medium (wastewater) [23]. Also, reduction of Ferricyanide from $\mathrm{Fe}(\mathrm{CN})_{6}{ }^{3-}$ to $\mathrm{Fe}(\mathrm{CN})_{6}{ }^{4-}[17]$ can also be responsible for the decrease in Open Circuit Voltage, current and power density.

The results from this study conducted using a dual-chamber MFC demonstrated that bioelectricity can be generated from swine wastewaters. This is in agreement with previous studies carried out by [19] who conducted similar studies using Swine wastewater. The results from this study revealed a maximum Open Circuit Voltage (OCV) of $836 \mathrm{mV}$, a Current of $0.49 \mathrm{~mA}$, and Power density of $88.46 \mathrm{~mW} / \mathrm{m}^{2}$.

The low Open Circuit Voltage can however be compared to a similar Open Circuit Voltage of $710 \mathrm{mV}$ generated in a study carried out by [24] using the same source of catholyte used in this study $\left(\mathrm{K}_{3}\left[\mathrm{Fe}(\mathrm{CN})_{6}\right]\right)$.

Also, the maximum Open Circuit Voltage of $836 \mathrm{mV}$ recorded in this study during the treatment of Swine wastewater is lower when compared to the maximum Open Circuit Voltage (OCV) if $1300 \mathrm{mV}$ recorded in a study carried out by [25] using Swine wastewater. However, Cassava starch served as their Proton exchange membrane in place of agar-agar used in this study. 
The low open circuit voltage recorded in this study could have resulted from a difference in the Proton exchange membrane used in various studies. Agar-salt bridge has a high internal resistance [4] and could be responsible for the low open circuit voltage and current. The reactor design could also have acted as a factor in the maximum open circuit voltage generated. [8] using a single chamber MFC reported a maximum power density of $261 \mathrm{~mW} / \mathrm{m}^{2}$ which is quite higher compared to $88.46 \mathrm{~mW} / \mathrm{m}^{2}$ generated in this present study. The difference in power density could have resulted from the use of different design and configuration. [13] reported a maximum open circuit voltage of $1560 \mathrm{mV}, 1400 \mathrm{mV}$ and $2890 \mathrm{mV}$ for the single dual-chambered, and the double dual-chambered in parallel and series respectively.

During operation of MFC, the open circuit voltage for swine wastewater increased within the first few hours and remained fairly constant for a considerable period of time. However, it is suggested from this study that the fairly uniform nature of the swine wastewater comprising mostly of urine $(45 \%)$ and swine faeces (55\%) and wash water could have played a major role as the bacteria community present in the swine wastewater were able to easily metabolize the substrate in the wastewater.

Furthermore, this study demonstrates the ability of a Microbial Fuel Cell to remove some nutrients from the wastewaters as shown in table 1 . The COD and BOD removal efficiency of $93.31 \%$, and $51.74 \%$ was recorded. This can be correlated to $86 \%$ COD removal efficiency reported in a study by [8]. Ammonia, Ammonia-Nitrogen, Ammonium, Nitrate, Nitrate-Nitrogen, Phosphorus, Orthophosphates and Phosphates were also examine to determine the effect of MFC on these parameters present in both Abattoir and Swine wastewater. The Nitrate, Nitrate-Nitrogen parameters were seen to increase by $131.65 \%$ and $134.85 \%$. The increase in Nitrate and NitrateNitrogen as observed in the swine wastewater may be due to nitrification likely as a result of oxygen diffusion through the cathode [1,8]. Phosphates, Phosphorus and Orthophosphates value increased by $168.77 \%, 159.26 \%$ and $157.03 \%$ respectively in Swine wastewater. The increase in Phosphates, Phosphorus and Orthophosphates could have been a result of stored phosphates in the bacteria [26], or the conversion of organic phosphorus in the wastewaters to different forms of phosphates [8].

Ammonia, Ammonia-Nitrogen and Ammonium rates decreased by 55.87\%, 55.79 and 55.9\% in swine wastewater respectively. This decrease could however have resulted from the process of nitrification, when ammonia in its various forms is converted first to nitrite then to nitrate[27].

\section{CONCLUSION/RECOMMENDATION}

The results from this study demonstrates that the dual-chamber MFC was able to treat swine wastewater demonstrating a COD and BOD removal efficiency of $85.92 \%$ and $51.74 \%$. The results from this study also underscores the role bacteria species such as Bacillus specie, Escherichia coli, Staphylococcus aureus, Streptococcus faecalis, Pseudomons aeruginosa and Corynebacterium specie play in the generation of electricity from wastewater and also in its treatment.

Electricity was generated using the wastewater as substrates with the dual-chamber MFC producing a maximum open circuit voltage of $758 \mathrm{mV}$ and $836 \mathrm{mV}$, current of $0.46 \mathrm{~mA}$ and $0.49 \mathrm{~mA}$ and power density of $66.43 \mathrm{~mW} / \mathrm{m}^{2}$ and $88.46 \mathrm{~mW} / \mathrm{m}^{2}$ for abattoir and swine wastewaters. The electricity generated was not constant throughout the 21 day period of operation. However, from the comparison of abattoir and swine wastewater as possible substrate for electricity generation using MFC, this study revealed that swine wastewater will serve more as a better anodic substrate compared to abattoir wastewater. Also, it was observed that aside the reduction of the catholytes which contributed to the low open circuit voltage and current, the system design also acted as a factor in voltage production. More research is needed to overcome the dwindling nature of the Voltage produced by the microbial fuel cell. Considering the duration of treatment, the rate of treatment and treatment time needs to be worked upon so that the technology can reach maturity. 


\section{REFERENCES}

[1] B.E. Logan. Microbial Fuel Cell. John Wiley and Sons Inc. New Jersey, US. 2007

[2] W.W. Li H.Q. Yu and He, Z. Towards sustainable wastewater treatment by using microbial fuel cells centered technologies. Energy \& Environmental Science, 7(3) (2014) 911-924.

[3] W. Heming P. Jae-Do and J. R. Zhiyong. Practical Energy Harvesting for Microbial Fuel Cells: A Review. Environ. Sci. Technol. 49 (2015) 3267-3277.

[4] B.E. Logan P. Aelterman B. Hamelers R. Rozendal, U. Schroder J. Keller S. Freguiac. W. Verstraete and K. Rabaey. Microbial fuel cells: methodology and technology. Environ. Sci. Technol. 40(17) (2006) 5181-5192.

[5] R. K. Jung D. Jerzy A. B. Mary and B. E. Logan. Removal of Odors from Swine Wastewater by Using Microbial Fuel Cells. Appl Environ Microbiol. 74 (8) (2008) 2540-2543.

[6] R.S. Lokhande U.S. Pravin and S.P. Deepali Study on physicochemical parameters of wastewater effluents from Taloja industrial are of Mumbai, India. Inter. Jour. of Ecosys, 1(1) (2011) 1-9

[7] R. E. Buchanan and N. E. Gibbon. Bergey's Manual of Determinative Bacteriology. 8th ed. The Williams and Wilkin's Co. Baltimore. (1984) pp 1246-1249.

[8] B. Min J.R. Kim S.E. Oh J.M. Regan and B.E. Logan. Electricity generation from swine wastewater using microbial fuel cells. Wat. Res., 39(20) (2005) 4961-4968.

[9] B.E. Logan. Simultaneous wastewater treatment and biological electricity generation. Water Science and Technology. 52 (2005) 31-37.

[10] H.J. Kim H.S. Park, M.S. Hyun I.S. Chang M. Kim and B.H. Kim. A mediator-less microbial fuel cell using a metal reducing bacterium, Shewanella putrefaciens. Enzyme Microb. Technol. 30(2) (2002) 145-152.

[11] D.H. Park and J.G. Zeikus. Impact of electrode composition on electricity generation in a single-copartment fuel cell using Shewanella putrefucians. Appl. Microbiol. Biotechnol. 59 (2002) 58-61

[12] K. Rabaey N. Boon, M. Hofte and W. Verstraete. Microbial phenazine production enhances electron transfer in biofuel cells. Environ. Sci. Technol. 39(9) (2005) 340 1-3408.

[13] O.L. Momoh and B.A. Naeyor. A novel electron acceptor for microbial fuel cells: Nature of circuit connection on internal resistance. Jour of Biochem, Tech. 2 (2010) 216-220.

[14] A.S. Mathuriya and V.N. Sharma. Electricity Generation by Saccharomyces cerevisae and Clostridium acetobutylicum via Microbial Fuel Cell Technology: A Comparative Study. Adv.in Bio. Res. 4 (4): (2009) 217-223

[15] A.S. Finch T.D. Mackie C.J. Sund, and J.J. Sumner. Metabolite analysis of Clostridium acetobutylicum: fermentation in a microbial fuel cell. Bioresour Technol., 102(1) (2011) 312 315.

[16] H.P. Bennetto. Electricity Generation from Microorganisms. Biotech. Edu., 1(4) (1990)163 168.

[17] J.C. Biffinger L.A. Fitzgerald R. Ray B.J. Little S.E. Lizewski E.R. Petersen B.R. Ringeisen W.C. Sanders P.E. Sheehan J.J. Pietron J.W. Baldwin L.J. Nadeau G.R. Johnson M. Ribbens S.E. Finkel and K.H. Nealson. The utility of Shewanella japonica for microbial fuel cells. Bioresour Technol., 102(1) (2011) 290-297. 
[18] X. Xia X.X. Cao P. Liang, X. Huang S.P. Yang and G.G. Zhao Electricity generation from glucose by a Klebsiella sp. in microbial fuel cells. Appl. Microbiol. Biotechnol., 87(1) (2010) 383-390.

[19] M. Liu Y. Yuan L.X. Zhang L. Zhuang S.G. Zhou and J.R. Ni. Bioelectricity generation by a Gram-positive Corynebacterium sp. strain MFC03 under alkaline condition in microbial fuel cells. Bioresour Technol., 101(6) (2010) 1807-1811.

[20] A.V. Samrot P. Senthikumar K. Pavankumar G.C. Akilandeswari, N. Rajalakshmi and K.S. Dhathathreyan. Electricity generation by Enterobacter cloacae SU-1 in mediator less microbial fuel cell. Int. J. Hydrogen Energy, 35(15) (2010) 7723- 7729

[21] S. Freguia K. Rabaey Z. Yuan and J. Keller. Electron and carbon balances in microbial fuel cells reveal temporary bacterial storage behavior during electricity generation. Environ. Sci. Technol. 41(8) (2007) 2915-2921.

[22] D. Borah M. Sejal and R.N.S. Yadav Construction of Double Chambered Microbial Fuel Cell (MFC) Using Household Materials and Bacillus megaterium Isolate from Tea Garden Soil. Adv. in Bio.l Res., 7 (5) (2013) 136-140.

[23] V.D. Patil D.B. Patil S.S. Pawar S.V. Otari M.B. Deshmukh and S.H. Pawar. Studies on electrochemical performance of microbial fuel cell based on dairy waste for energy conversion. Inter. Jour of Chem Sciences and Appli.4 (2) (2013) 111-115

[24] N. Guerrero-Rangel J.A. Rodríguez-de la Garza, Y. Garza-García, L.J. Ríos-González, G.J. Sosa-Santillán, I.M. De la Garza-Rodríguez, S.Y. Martínez-Amador, M.M. Rodriguez Garza and J. Rodríguez-Martínez. Comparative study of three cathodic electron acceptors on the performance of mediatorless microbial fuel cell. Int. J. Electric. Power Eng., 4(1) (2010) 2731.

[25] L.A. Obasi C. C. Opara and A. Oji. "Performance of Cassava Starch as a Proton Exchange Membrane in a Single Dual Chamber Microbial Fuel Cell" International Journal of Engineering Science and Technology (IJEST), 4 (1) (2012) 227-238.

[26] H. Liu, H. Ramnarayanan and B.E. Logan. Production of electricity during wastewater treatment using a single chamber microbial fuel cell. Environ Sci. Technol.,38(7) (2004) 2281-2285.

[27] G. Bitton, Wastewater Microbiology, 3rd Edition. John Wiley and sons Inc. Hoboken, New Jersey 2005 